\title{
Relationship of Criminal Proceedings to Civil Litigation, Insolvency and Tax Proceedings
}

\author{
Pavel Kotlán ${ }^{1}$
}

\begin{abstract}
The main goal of this article is to clarify the nature of criminal proceedings and its relationship to civil litigation, insolvency and tax proceedings. The understanding of the purpose of the proceedings, the nature of the liability fulfilled in the proceedings and the principles on which the proceeding is based can facilitate the investigation of economic crime by the prosecuting authorities. The results of the work lead to the conclusion that key factors are the purposes of each proceedings and differences in the principles by which they are governed. But legal norms are not always unambiguous - for instance, in the issue of the so-called punitive damages, the relationship between collateral proceedings and insolvency proceedings or the nature of penalties under Art. 251 of the Tax Code.
\end{abstract}

\section{Keywords}

Criminal Proceedings, Economic Crime, Insolvency Proceedings, Civil Litigation Proceedings, Tax Proceedings

\section{Introduction}

When analysing economic crime, i.e. non-violent crime committed by a person involved in business as part of a business activity, the purpose of which is, albeit indirectly, to gain an unjustified economic benefit or to cause property damage, the issue of conducting civil litigation, insolvency and tax proceedings is encountered. Clarification of the nature of individual proceedings and their relationship to criminal proceedings is key to the correct determination of criminal liability and the procedure of prosecuting authorities, especially when clarifying crimes related to property, insolvency and taxes. It is the understanding of the interrelationships, often of parallel proceedings, that can help bridge the deepening sectoral specialisation.

The key factor for defining this relationship is the purpose of the proceedings in question and the related nature of the decision, i.e. whether the decision corrects private law relationships or is the implementation of a society-wide need. The conclusions reached

\footnotetext{
${ }^{1}$ PRIGO University, Vítězslava Nezvala 801/1, 73601 Haviŕov, Czech Republic. E-mail: pavel.kotlan @ prigo.cz.
} 
by the applying prosecuting authority are in turn conditioned by the principles by which the proceedings are controlled; in particular by those principles determining the initiation and course of proceedings and the nature and extent of taking of evidence.

The characteristics of each procedure and the determination of its relationship to the criminal proceeding will thus depend on determining the purpose of the proceeding, the nature of the liability fulfilled in the proceeding and the principles on which the proceeding is based.

The purpose of every proceeding is to implement a certain legal liability, in principle either a private law or a public law liability. The nature of the pursued liability is obviously also reflected in the nature of the applying body's decision, which is either a decision that settles the legal relationship of the entities concerned (corrective justice) or a decision which implements the public interest (society-wide justice ${ }^{2}$ ). ${ }^{3}$ In other words, the purpose of private law liability is mainly to compensate for damages, while the purpose of public law liability is to ensure compliance with, or punish the violation of, society-wide values. ${ }^{4}$ The actual course of a proceeding before a public authority is then determined primarily by which of the following two conflicting principles is applied and to what extent:

* the principle of uniformity of proceedings versus the principle of concentration of proceedings,

* the principle of disposition versus the principle of officiality,

* the adversarial principle versus the inquisitional principle.

\section{Criminal proceedings and its relationship to other proceedings (in general)}

The purpose of criminal proceedings is to identify and punish the perpetrator of a crime, i.e. "to establish in a legally valid manner that a person has committed a certain criminal offence, and to find out which punishment for that particular offence is a legal punishment." 5 In this way, society-wide justice is actually applied to the person who has committed the most serious form of tort (crime). ${ }^{6}$ A decision in criminal proceedings, of course, if it is a criminal offence and if the offender is identified, is therefore a sanction in nature.

A part of the criminal proceeding, however, is also the collateral proceeding as a certain penetration of corrective justice into criminal law. The reason for many criminal complaints concerning economic crime is precisely the existence of this collateral procedure. Its purpose is to satisfy the injured party's private law claim for compensation for damages. ${ }^{7}$

\footnotetext{
${ }^{2}$ Protection of "all those values which may be shared among the citizens of an organised state." Aristotle (2004). ${ }^{3}$ Aristotle (2004), and Janeček (2017) use the term "distributive justice" instead of the term "society-wide justice". However, in the context of criminal liability, this could be confusing, so I have chosen the term 'society-wide'.

${ }^{4}$ Criminal liability "lacks a reparative effect” and civil liability "lacks a repressive effect” (Knapp, 1983).

5 Storch, Spáčil (2011).

${ }^{6}$ The legal norm (in the form of a prohibition) points to illegal actions, and the criminal law to criminal acts (Binding, 1872). In the broader social context, one can agree with Roxin that the justification for the existence of criminal law is the resolution of social conflicts (Roxin, 1973).

${ }^{7}$ At the same time, compensation for damages in collateral proceedings cannot be exercised if "the claim has already been decided in a civil or another relevant proceeding” (Art. 44 (3) of the Criminal Procedure Code).
} 
In that part in which the claim is satisfied in criminal proceedings (in principle the direct and the actual damage), it is no longer possible to call for a claim in a civil procedure. ${ }^{8}$ Storch's opinion is apt for the relationship between collateral proceedings and actual criminal proceedings: "According to the substantive content of the two claims in question, there is in fact a double proceeding, on a criminal and a civil matter, merged into one which, in terms of external forms, even in the case of a civil case, preserves the nature of a criminal proceeding." 9

The principle of uniformity of proceedings has effect in criminal proceedings, i.e. legal and factual arguments may be applied at any stage. Evidence can thus in principle be taken of indefinitely throughout the (regular) criminal proceedings; even an appeal may be based on new facts and evidence (Art. 249 (3) of the Criminal Procedure Code).

The initiation and course of proceedings are determined by the principle of officiality and the inquisitional principle. Due to the principle of officiality, the initiation of criminal proceedings and - with the exception of the somewhat problematic non-granting of the injured party's consent as defined in Art. 163 of the Criminal Procedure Code $^{10}-$ as well as on its further conduct is decided on by a prosecuting authority.

In terms of the inquisitional principle, prosecuting authorities are themselves obliged to secure the evidence of the crime committed by the accused. Since these authorities must identify the "facts of the case of which there are no reasonable doubts" (Art. 2 (5) of the Criminal Procedure Code), the subsequent confession of the accused does not release them from the obligation to investigate the case properly (e.g. it may turn out that the accused is covering by false confession another person). Proceedings controlled by the inquisitional principle necessarily lead to the ascertaining of material truth, i.e. the ascertaining of the facts without formal restrictions. ${ }^{11}$

At present, the right of the injured party to the so-called effective investigation is significantly reflected, which, however, does not affect the modification of the above principles, or more precisely, it can be seen as an affirmation of these principles, as it is a requirement for prosecuting authorities to make "qualified efforts to clarify the suspicion of a criminal offence". ${ }^{12}$ Such an approach is a necessary consequence of the role of criminal law, which primarily sanctions "public wrong", i.e. an attack on society as a whole, not just on an individual victim. ${ }^{13}$

The relationship of criminal proceedings to other proceedings is determined in particular by the provisions on the preliminary ruling pursuant to Art. 9 of the Criminal Procedure

\footnotetext{
${ }^{8}$ The exercise of a claim for damages and the punishment have in common only that the offender loses their legal right ("Rechtsgut") (Berolzheimer, 1903).

${ }^{9}$ Storch, Spáčil (2011).

${ }^{10}$ See Jelínek (2017), or Kotlán (2018b).

11 „Zjištění skutkového stavu neklade... žádné formální překážky“ ["Identifying the facts does not constitute... any formal obstacles."] (Winterová, Macková, 2015).

${ }^{12}$ Finding of the Constitutional Court of the Czech Republic of 3. 9. 2018, file no. III. ÚS 2012/18. And as another judgment of the Constitutional Court states, this right guarantees the injured party "no specific result, but only the correctness of the procedure of the body in question". Finding of the Constitutional Court of the Czech Republic of 19. 1. 2016, file no. II. ÚS 3436/14.

${ }^{13}$ Ashworth, Horder (2013).
} 
Code. As defined in this provision, a prosecuting authority is bound by a decision of another body (in different proceedings) if it is not "assessment of the guilt of the accused" (Art. 9 (1) of the Criminal Procedure Code). The phrase "guilt of the accused" must be interpreted (and the courts do) relatively extensively, specifically with regard to the different purpose and principles that are related to individual proceedings. ${ }^{14}$ So, e.g., the conclusion that the legitimacy of a claim which is made by a court in a civil litigation proceeding or the decision of a tax administrator on the amount of tax liability are not binding on the prosecuting authority (see below). If other proceedings contain a decision different from the view of the prosecuting authority, it is appropriate for the latter to deal with this conclusion in an argumentative way. ${ }^{15}$

On the other hand, however, the court is not authorised to decide in criminal proceedings - with the exception of the above-mentioned compensation - on private law issues (e.g. on the right of ownership ${ }^{16}$ ). Accordingly, as defined in Art. 9 (2) of the Criminal Procedure Code, a prosecuting authority is not authorised to (independently) resolve issues related to the personal status, which are the subject of the civil procedure.

\section{Civil litigation proceedings and their relationship to criminal proceedings}

The purpose of the civil litigation proceeding is described in the introductory provisions of the Code of Civil Procedure, i.e. that it "regulates the procedure of the court and the participants in civil court proceedings so as to ensure fair protection of private law and legitimate interests of the participants..." (Art. 1 of the Code of Civil Procedure). In other words, the civil litigation proceeding is an instrument for private law liability by correcting private law relationships. There is no reason, however, not to exercise criminal (public) liability, pursuing a different purpose, in addition to private law liability, which is exercised in civil litigation proceedings. As a decision of the Supreme Court aptly states: "with the exception of the review of Art. 9 of the Criminal Procedure Code and Art. 135 of the Code of Civil Procedure", the proceedings "are independent of each other. It is not excluded, however, that both proceedings on a certain related subject matter may be conducted simultaneously. In doing so, one legal relationship may be considered by the civil court as a relationship between the creditor and the debtor, and the court exercising criminal justice as a relationship between the injured and the accused." 17 If, for example, the plaintiff achieves a relative ineffectiveness of legal action on the basis of the so-called action to set a transaction aside (Art. 589 of the Civil Code), this does not mean that the defendant, accused in a criminal proceeding, may not be sentenced of a criminal offence whose facts of the case rest in reduced satisfaction of the creditor's enforceable claim (see the criminal offence of damaging the creditor pursuant to Art. 222 of the Criminal Code). This fact cannot be changed not even by certain tendencies that the compensation for

\footnotetext{
${ }^{14}$ Musil, Kratochvíl, Šámal (2003).

${ }^{15}$ Decision of the Supreme Court of the Czech Republic of 31. 8. 2011, file no. 8 Tdo 624/2011.

${ }^{16}$ In the case of property right, it will be decided on by the court in civil litigation proceedings. Finding of the Constitutional Court of 23. 2. 2015, file no. I. ÚS 2307/13.

${ }^{17}$ Decision of the Supreme Court of the Czech Republic of 18. 12. 2013, file no. 8 Tdo 1268/2013.
} 
damages includes punitive elements (the so-called punitive damages $\left.{ }^{18}\right)^{19}$ or incorrect inferring that the application or possibility of private law defence have an effect on criminal liability, or more precisely, that it implies impunity. ${ }^{20}$

Significant elements of concentration of proceedings appear in civil litigation proceedings, which limit (concentrate) the possibility to propose evidence until a certain point in the proceeding (e.g. only in first-instance proceedings or until the court's first hearing (see Art. $118 \mathrm{~b}$ of the Code of Civil Procedure). ${ }^{21}$ This, of course, significantly affects the court's conclusion as it can in principle be based only on the statements and evidence proposed by the parties by a certain moment of the proceedings.

Civil litigation proceedings are based on the principle of disposition and the adversarial principle. The principle of disposition, which is based on the idea that the initiative should be taken by the one who defends their legal interest, ${ }^{22}$ gives the right to the participant to dispose of the proceeding, i.e. the commencement of the proceeding and the procedure thereof depend on the procedural initiative of the parties to the proceeding. ${ }^{23}$ If, for example, the plaintiff agrees with the defendant and there is no interest in further court proceedings, they may withdraw the action pursuant to Art. 96 (1) of the Code of Civil Procedure, which means the court ceases the proceedings. ${ }^{24}$

The adversarial principle, naturally following it, expresses the fact that the court hears only what the parties submit (burden of raising and presenting the issues); failure to bear the burden of proof then means failure in the dispute. ${ }^{25}$ As a rule, the court will not hear other evidence than what is proposed by the parties as defined in Art. 120 (2) of the Code of Civil Procedure (will not address, e.g. the authenticity of a loan agreement unless the authenticity has been contested). ${ }^{26}$ The court's decision is thus not necessarily identical to reality but is a reflection of the procedural activity of the parties to the dispute, i.e. the result is the so-called formal truth. As Storch argues: "A civil judge giveth a judgment based on facts which the parties themselves, in so far as the right of disposition extends to them, modify and submit at their own discretion, so that a judgment is not always completely

\footnotetext{
18 "Damages, other than compensatory or nominal damages, awarded against a person to punish him for his outrageous conduct and to deter him and others like him from similar conduct in the future" (Meurkens, Nordin, 2012).

${ }^{19}$ On the dangerous consequences of such an approach, see Gerloch, Beran (2014).

${ }^{20}$ For more details, see Kotlán (2018a).

21 The concentration of the proceedings is, in fact, based on the view that any dispute should be "eliminated" as soon as possible ('bald aus der Welt schaffen') (Klein, Engel, 1927).

22 Winterová, Macková (2015).

23 Nagel (1967).

${ }^{24}$ Complainants in criminal proceedings do not always understand the difference between the principle of disposition and the principle of officiality, which governs criminal proceedings, so they sometimes demand a sort of withdrawal of their criminal complaint after the suspect has paid the amount owed. However, if there is still a suspicion of a committed criminal offence (e.g. fraud pursuant to Art. 209 of the Criminal Code), then such withdrawal is legally irrelevant, and the police authority continues to investigate the matter.

25 The principle that no one has to prove what they have not had to say before is applied (Balzer, Walther, 2018). For more details on taking of evidence, see Lavický (2017).

${ }^{26}$ If this principle is expressed more strongly, the court may not use its own knowledge to supplement or correct the substantive proposal of the party to the dispute (Nagel, 1967).
} 
comparable to the material truth, which a criminal judge may heed only." 27 The decision of a civil court may therefore be quite different from the decision of a prosecuting authority that is examining a similar factual question. This is most noticeable in the so-called default judgment: If the defendant does not appear at the first hearing without adequate excuse, "the plaintiff's statements contained in the action on the factual circumstances concerning the dispute are considered indisputable, and the court may decide on the action by default judgment on this basis" (Art. 153b (1) of the Code of Civil Procedure). The action will undoubtedly be decided on in favour of the plaintiff, regardless of the actual (material) situation. Such decision of the civil court, therefore, does not release the prosecuting authority from the obligation to examine the real existence of the claim, its amount, etc. The principles governing civil litigation proceedings are quite contradictory to criminal proceedings, and therefore the conclusions of one proceeding may not always be relevant to the other. A prosecuting authority must therefore be particularly aware that a civil court decision may have the nature of formal truth, which is the result of failure to bear the burden of raising and presenting the issues or the burden of proof, rather than reflecting on the material (actual) state.

The relation of civil litigation proceedings to criminal proceedings is addressed in particular by Art. 135 (1) of the Code of Civil Procedure: "The court shall be bound by the decision of the competent authorities that a criminal offence has been committed. . ." If a prosecuting authority has reached a certain conclusion in another issue, then the civil court... "proceeds from it" (Art. 135 (2) of the Code of Civil Procedure), i.e. it is (similarly for a prosecuting authority when assessing the preliminary question) its basis for further consideration, with the possibility of "re-arguing" it.

The findings of a prosecuting authority are therefore binding on a court in a civil procedure only if they relate to a finding that a criminal offence has been committed. If this is compared with the limit that the "criminal" court has, i.e. the decision on personal status, which is decided by the civil court, it is concluded that the powers of both bodies are similar and in deciding on the responsibility to be exercised are essentially also independent, apart from the exceptions mentioned.

Civil litigation proceedings, such as private law liability, pursues a different purpose than criminal proceedings do and is independent of it in that regard. The intersection of both proceedings occurs mainly in cases where a compensation for damages has been (partially) claimed in a collateral proceeding, which is part of the criminal proceedings. Then it is true that a civil procedure on this matter cannot be conducted (and vice versa - collateral proceedings cannot be conducted to compensate for damage that has been successfully sued). The evidence of the connection between criminal and civil litigation proceedings and the expression that corrective justice is realised through collateral proceedings is, among other things, the fact that the exercised compensation for damages in criminal proceedings suspends the limitation period to exercise a claim in the civil litigation proceeding. ${ }^{28}$

\footnotetext{
${ }^{27}$ Storch, Spáčil (2011).

${ }^{28}$ Decision of the Supreme Court of 24. 5. 2006, file no. 25 Cdo 2478/2004 (the amount and legal reason for the claim must be evident, however, e.g. as early as in the criminal complaint).
} 
In the case of economic crime, there is often a situation in practice where both proceedings, conducted at the same time, are indirectly influenced by the attitude of individual actors. So, for example, a person examined in a criminal proceeding who is simultaneously also the defendant in a civil proceeding reacts to the current situation in the respective proceeding when evidence is taken of. To some extent, this constitutes a schizophrenic position for the suspect or defendant - i.e. the need to bring evidence in their defence in the civil dispute and the possibility not to bring any evidence in the criminal proceeding.

The state of a civil dispute may at some point have an immediate effect on the legal classification of the offence. Thus, for example, the disposition of a (potential) debtor who is sued in a civil proceeding with their property may constitute a criminal offence of damaging the creditor pursuant to Art. 222 of the Criminal Code. The decisive factor is the state of the civil procedure, as the suspect's or defendant's intention to thwart the creditor's satisfaction by stealing their own property can be inferred precisely from the presumption of failure in a civil dispute. ${ }^{29}$ Similarly, when clarifying economic crime for criminal proceedings, it is important to evaluate the course and decisions of the civil procedure within the assessment of criminal liability for the crimes of false testimony and untruthful expert opinion pursuant to Art. 346 of the Criminal Code in those cases where the testimony of a witness in a civil dispute participating in the business of one entity is driven by an effort to provide an economic advantage to another entity (see the wording of Art. 346 (2)(a) of the Criminal Code "shall state falsehood about a circumstance that is essential for the decision"); most recently, criminal law will also observe the submission of forged (private) documents after the facts of obstructing justice under Art. 347a of the Criminal Code have been introduced. ${ }^{30}$

It should be noted that criminal proceedings are becoming a welcome means of gaining an advantage over one's commercial competitor in the context of conflicting business relationships. As a result of filing a criminal complaint, which, unlike a lawsuit, is free of charge, and applying different principles in criminal and civil litigation proceedings, the complainant suspects a committed criminal offence, and, at the same time, the (potential) plaintiff has the possibility to transfer the activity of securing evidence to prosecuting authorities and use the results in this activity in the civil dispute. However, there are opposite cases as well, where the defendant in a civil proceeding opts for a criminal complaint as their "counter-attack" in order to somehow intimidate the plaintiff. ${ }^{31}$

\section{Insolvency proceedings and their relationship to criminal proceedings}

The purpose of an insolvency proceeding is to organise the property relations of a debtor who is in (imminent) insolvency, i.e. to satisfy the private law claims of creditors. It is therefore necessary to reject the statement that the application of the debtor's private law

\footnotetext{
${ }^{29}$ E.g. the offence of damaging a creditor is committed when the civil procedure is at the stage of hearing the defendant's remedy against the judgment establishing their obligation towards the creditor.

${ }^{30}$ For various aspects of these new constituent elements, see Provazník (2019).

${ }^{31}$ E.g. a plaintiff who has exercised their right of retention in respect of the defendant's case in order to satisfy their claim is reported by the defendant as a suspect of embezzlement.
} 
liability in an insolvency proceeding may affect the subsidiarity of penal repression. ${ }^{32}$ Considering the fact that the condition for conducting an insolvency proceeding is the multiplicity of creditors (Art. 3 (1)(a) of Insolvency Act No. 182/2006 Coll., as amended (Insolvency Act), it is a matter to satisfy rights in a collective manner. ${ }^{33}$ As in the case of civil litigation proceedings, the simultaneous conduct of a criminal proceeding representing society-wide justice is not excluded here. Such situation occurs regularly it is usual that in the case of a crime investigation related to a debtor's insolvency, an insolvency proceeding will be conducted as well.

When taking of evidence in insolvency proceedings, the use of concentration is excluded, even within the application of the subsidiarity of the Code of Civil Procedure. ${ }^{34}$ The element of concentration of proceedings could be only seen in relation to the deadline for filing a claim which the creditor may submit "from the commencement of the insolvency proceeding until the deadline set by the decision on insolvency has expired", while "the insolvency court disregards applications that are submitted later and such claims are not satisfied in insolvency proceedings" (Art. 173 (1) of the Insolvency Act); or in the case of a creditor who must exercise their claim, denied by the insolvency administrator, within the statutory time limit before the insolvency court (Art. 198 (1) of the Insolvency Act). It is the principle of disposition that is typical for the commencement and course of insolvency proceedings, i.e. the proceeding begins only at the proposal of the debtor or the creditor (Art. 97 and the following Insolvency Act). The insolvency petitioner is empowered to "withdraw the insolvency petition until the decision on insolvency has been given or another decision on insolvency petition has taken effect" (Art. 129 (1) of the Insolvency Act). The principle of officiality is manifested only exceptionally in the supervisory activities of the insolvency court and in preliminary measures which are not for the claim. ${ }^{35}$

In contrast to the civil litigation proceedings, the principle of disposition is not linked to the adversarial principle but to the inquisitional principle, which is documented in particular in Art. 86 of the Insolvency Act: "In insolvency proceedings, the insolvency court is obliged to provide also other proofs necessary to certify the debtor's insolvency or imminent insolvency than those proposed by the participants." This undoubtedly leads to the fact that the finding of the insolvency court or administrator corresponds more to the material truth and thus comes closer to the conclusion reached by the prosecuting authority on the same issues (e.g. finding of insolvency or the amount of the claim). ${ }^{36}$ The relationship of insolvency proceedings to criminal proceedings is generally determined, with regard to the subsidiary application of the Code of Civil Procedure (see Art. 7 of the Insolvency Act), by the mentioned provision of Art. 135 of the Code of

\footnotetext{
32 Púry (2015). Argumentation against Kotlán (2018a).

33 "Ein System kollektiver Rechtsverfolgung unter gerichtlicher Aufsicht, das auf die gleich mässige Befriedigung der (unbesicherten) Gläubiger abzielt" (A legal procedure which, under the supervision of a court, collectively satisfies the claims of (unsecured) creditors, see Fink, 2017).

34 Winterová, Macková (2015).

35 Ibid.

${ }^{36}$ Similarly, the principle of disposition and inquisitional principle are intertwined in German insolvency proceedings. See Rechberger, Seeber, Thurner (2018).
} 
Civil Procedure, i.e. it shows in principle the independence of both proceedings. ${ }^{37}$ This is also confirmed by the provisions concerning bankruptcy, i.e. the non-remedial form of insolvency solution, where the criminal proceeding is not interrupted with the declaration of bankruptcy as defined in Art. 266 (1) (a) of the Insolvency Act. Insolvency proceedings actually replace civil litigation proceedings (see Art. 109 (1) (a) of the Insolvency Act). The principles on which insolvency proceedings are based are fundamentally closer to civil litigation proceedings, ${ }^{38}$ although particularly the application of the inquisitive principle means that the conclusions of insolvency proceedings are close to the conclusions of prosecuting authorities. Naturally, Art. 9 of the Criminal Procedure Code on the resolution of preliminary rulings apply here as well. Thus, even if the insolvency court concludes on the debtor's insolvency, the existence or the amount of a certain claim, this does not release the prosecuting authority from the obligation to deal with these conclusions as with a preliminary ruling as defined in Art. 9 (1) of the Criminal Procedure Code. ${ }^{39}$ The facts of the so-called insolvency offences or criminal offences ${ }^{40}$ are in terms of terminology and factuality influenced by the Insolvency Act - for example, in the definition of insolvency or in defining the categories of claims and the rules to satisfy them. However, it is appropriate to perceive also here the delimitation in the Insolvency Act through the prism of Art. 9 (1) of the Criminal Procedure Code, i.e. as a separate issue addressed by a prosecuting authority from the perspective of guilt assessment. This is evident when determining insolvency, where a rebuttable presumption of insolvency pursuant to Art. 3 (2) of the Insolvency Act is significant for the definition of insolvency in insolvency proceedings but not in criminal proceedings. ${ }^{41}$

The classification of claims according to the Insolvency Act for offences of benefiting creditors pursuant to Art. 223 of the Criminal Code may therefore have a fundamental effect on criminal liability. If, for example, a suspect pays a debt to a secured creditor when the company the suspect is acting for is insolvent, whose claim is paid up to the full amount of the security, then it cannot be said (in the material sense) that the creditor has been favoured. If a security (e.g. a lien on real estate) was sufficient to cover the debtor's obligation, they would still be satisfied in full from the debtor's property. ${ }^{42}$

\footnotetext{
${ }^{37}$ See also Púry (2015).

${ }^{38}$ An even more significant nature of civil dispute can be seen in the resolution of the so-called incidental disputes, i.e. the resolution of disputed legal issues outside insolvency proceedings, at the proposal of an authorised person resolved at an insolvency court (Winterová, Macková, 2015).

${ }^{39}$ The controversial question remains, however, whether the "state of insolvency" is not the personal status of the person concerned, i.e. whether the decision on insolvency of the insolvency court would not have to be respected as defined in Art 9 (2) of the Criminal Procedure Code. For more, information, see the analysis in Púry (2015). In any case, the Supreme Court considers the resolution on the declaration of bankruptcy of the debtor's property, the precondition of which is the finding of their insolvency, to be the decision on personal status. Decision of the Supreme Court of the Czech Republic of 30. 4. 2014, file no. 29 Cdo 1658/2012.

${ }^{40}$ This term is, however, somewhat misleading because some constituent elements are classified as insolvency offence, though insolvency is not their legal characteristic. See, for example, the damage to the creditor under Art. 222 of the Criminal Code.

${ }^{41}$ As Pelz rightly points out in that regard, the principle of the unity of the legal order does not exclude that identical terms have different meanings in different branches of law (Pelz, 2011).

${ }^{42}$ As defined in Art. 167 (1), Art. 168 (3), Art. 169 (2) and Art. 305 of the Insolvency Act. For more details, see Kotlán (2015).
} 
Uncertainties arise in the relationship of insolvency proceedings to collateral proceedings. If the collateral proceeding is a sort of possibility to implement private law liability in a criminal proceeding instead of a civil litigation proceeding, then logically the provision of Art. 109 (1) (a) of the Insolvency Act should be applied, i.e. the impossibility to assert one's claim after the insolvency proceeding has commenced other than by applying for an insolvency proceeding as well as for a collateral proceeding. ${ }^{43}$ Besides, as defined in Art. 140b of the Insolvency Act, it is not possible to decide on the injured creditor's claim in a criminal proceeding (if it is not property from the debtor's assets secured in a criminal proceeding). ${ }^{44}$ Therefore, in a situation where an insolvency proceeding is being conducted against a debtor, the court should proceed in relation to the claim of the injured party in a criminal proceeding as defined in Art. 206 (3) and (4) of the Criminal Procedure Code, i.e. not to admit the injured party to the main hearing and refer them to the insolvency proceeding as defined in Art. 229 (1) of the Criminal Procedure Code. ${ }^{45}$ This, of course, has also an impact on the procedure of the police authority carrying out actions in relation to the injured party and their claims to compensation for damages.

\section{Tax proceedings and their relationship to criminal proceedings}

The purpose of a tax proceeding is to correctly identify and determine a tax and to ensure its payment (see Art. 1 (2) of the Tax Code). Ensuring payment must be understood not only as the procedure for tax collection but also for penalty payment pursuant to Art. 251 of the Tax Code (Act No. 280/2009 Coll., The Tax Code, as amended), which will be significant for the relationship to criminal proceedings (see below). Taxes are the basic revenue of public budgets, so their correct determination and collection is undoubtedly the implementation of public law liability. A very specific element of tax proceedings, which fundamentally distinguishes them from administrative and criminal proceedings, is the so-called self-assessment obligation, i.e. the taxpayer's obligation to file a proper tax declaration (Art. 135 (1) of the Tax Code). ${ }^{46}$ The tax administrator imposes the tax based on that statement. If the tax administrator reveals a finding different from the taxpayer's declaration, the tax is imposed correctly and the taxpayer is also sanctioned with a penalty according to Art. 251 of the Tax Code.

The concentration of proceedings shall not apply in tax proceedings, as the appellate body may take of evidence to supplement the documents for the decision even in appeal proceedings (Art. 115 (1) of the Tax Code), i.e. "to supplement essentially any evidence or tools if it deems it appropriate and if it does so within the limits of legal restrictions." Tax proceedings, as a typical procedure concerning the application of public law liability,

\footnotetext{
${ }^{43}$ The Supreme Court did not cope with this argument in any way in its decision when it broadly inferred from the wording of Art. 266 (1) (a) of the Insolvency Act that there is no obstacle to the decision on compensation for damages in collateral proceedings under Art. 228 of the Criminal Code. Decision of the Supreme Court of the Czech Republic of 11. 9. 2013, file no. 7 Tdo 677/2013.

${ }^{44}$ Púry (2015), p. 192-194 deals with it in detail.

${ }^{45}$ See also Petrák (2016).

${ }^{46}$ The specificity of the tax proceeding can also be seen in the fact that "it is continuous with the existence of tax liability unless the objective of the tax administration has been achieved" (Bakeš, 2012).

${ }^{47}$ Judgment of the Supreme Administrative Court of the Czech Republic of 30. 1. 2015, file no. 5 Afs 143/2014.
} 
are conducted with the principle of officiality. This means that the tax administrator is obliged, also on its own initiative, to commence a proceeding whenever the legal conditions for the creation or existence of a tax claim are met. ${ }^{48}$

The procedure in tax proceedings is determined by the inquisitional principle, albeit with some modification. The initial provision is Art. 92 (2) of the Tax Code: "The tax administrator shall ensure that the facts decisive for the correct identification and assessment of a tax are identified as completely as possible, not bound only by taxpayers' proposals." The modification is caused by the burden of raising and presenting the issues and the burden of proof of the taxpayer, consisting mainly in the already mentioned obligation to file the tax declaration and prove the facts declared thereof. ${ }^{49}$ It might thus seem that the tax administrator may also come to the formally imposed tax, which is disadvantageous for the taxpayer, even though it would be aware of the fact that the tax is materially different. This is of course possible (e.g. if the taxpayer does not state a certain fact - see the burden of raising and presenting the issues or if the tax administrator determines the tax according to the tools under Art. 98 of the Tax Code) but with the limit that even without the taxpayer's cooperation, the tax administrator must direct its efforts to determine the amount of tax that is closest to reality. As stated by the Supreme Administrative Court, "the basic principles of tax proceedings as well as the principles of good governance and the requirement that citizens have confidence in fair and impartial decisions made by administrative bodies" result in the tax administrator's obligation to redetermine the tax amount even if it is found out that "the originally assessed tax obligation is incorrectly higher. . " 50

Tax proceedings are thus, in principle, aimed at identifying the material truth. In certain cases, however, in a case of insufficient evidence, the tax may be determined according to tools or agreed with the taxpayer (Art. 98 of the Tax Code), which is rather an expression of formal truth. ${ }^{51}$

The tax administrator in tax proceedings, of course, even with regard to the fact that it is not a judicial body, is generally bound by decisions of other public authorities (Art. 99 (1) of the Tax Code). In relation to criminal proceedings, it should be noted that it is not, among other things, authorised, in the context of assessing preliminary rulings, to decide whether a certain action is a criminal offence. On the other hand, as already mentioned, a prosecuting authority does not have such a limit in relation to the issues that are the subject of tax proceedings, and with regard to assessing preliminary rulings under Art. 9 (1) of the Criminal Procedure Code, it can therefore deal with the tax administrator's conclusion in

\footnotetext{
$\overline{48}$ Bakeš (1999). See also Art. 9 (2) of the Tax Code: "The tax administrator systematically provides the preconditions for the creation or continuation of the obligations of persons participating in tax administration and performs the necessary acts in order for these obligations to be fulfilled", and Art. 91 (2) of the Tax Code: "If a taxpayer fails to fulfil their obligation to make a submission to initiate a proceeding, the tax administrator initiates such proceeding ex officio as soon as the facts giving rise to that obligation are identified."

${ }^{49}$ For a clear overview, see Vašutová (2012).

${ }^{50}$ Judgment of the Supreme Administrative Court of the Czech Republic of 25. 7. 2007, file no. 1 Ans 1/2007.

${ }^{51}$ Even when determining a tax with tools, the tax administrator is still obliged to determine the tax base with the greatest possible degree of probability. Judgment of the Supreme Administrative Court of the Czech Republic of 28. 6. 2007, file no. 2 Afs 184/2006.
} 
an argumentative way. ${ }^{52}$ This is, incidentally, a necessary consequence of the modification of the inquisitional principle, where the tax administrator may come to a certain tax liability, which, however, - as a result of the taxpayer not bearing the tax burden - may not be in accordance with the facts. Thus, the additionally assessed tax in the tax proceeding may not correspond at all to the reduced tax in the criminal proceeding.

This stated modification of the inquisitional principle as well as the mentioned difference between the authorities conducting tax and criminal proceedings may then, in regard to a criminal proceeding, lead to a breach of the principle of nemo tenetur se ipsum accusare, i.e. to the prohibition of coercion to self-incrimination..$^{53}$ If the tax administrator comes to a suspicion of tax evasion in a tax proceeding, the taxpayer in the tax proceeding is forced to contribute evidence in order for the tax to be correctly assessed, which can be found in violation of the taxpayer's right to "remain silent" in criminal proceedings. ${ }^{54}$

Tax proceedings are an implementation of public law liability and therefore, under certain circumstances, may be in conflict with criminal proceedings. The merging of the two proceedings in the event of a violation of tax obligations may result in both criminal and tax penalties. ${ }^{55}$ This represents a problem with tax evasion which constitutes a criminal offence (Art. 240 of the Criminal Code) and also meets the conditions for imposing a penalty under Art. 251 of the Tax Code, which is under certain circumstances considered a penalty sui generis, and thus a possible violation of the principle of ne bis in idem.

The penalty under Art. 251 of the Tax Code has thus been the subject of a heated debate in recent years, and it is still unclear whether this sanction is of a punitive nature or not. If this were the case, then the simultaneous sanctioning with this penalty and the punishment for the criminal offence of evading taxes, fees and similar mandatory payments under Art 240 of the Criminal Code would be an inadmissible violation of the principle of ne bis in idem (see Article 4 (1) of Protocol 7 of the Convention for the Protection of Human Rights and Fundamental Freedoms). ${ }^{56}$ As a result of the decision of the Chamber of the Supreme Court of the Czech Republic, ${ }^{57}$ following the ruling of the European Court of Human Rights in the case of "A and B v. Norway", 58 the prevailing opinion is that the penalty under Art. 251 of the Tax Code does not, in certain circumstances, constitute an obstacle

\footnotetext{
52 The Supreme Court stated that the decision of the tax administrator on tax liability or advantage is a significant matter for guilt, and therefore it can be assessed by a prosecuting authority separately as a preliminary ruling, e.g. in the Decision of the Supreme Court of the Czech Republic of 7. 8. 2013, file no. 5 Tdo 693/2013.

${ }^{53}$ Seer, Wilms, Radvan (2016).

${ }^{54}$ The principle of nemo tenetur follows directly from the Charter, particularly the right not to testify pursuant to Articles 37 (1) and 40 (4), which are further elaborated in the relevant provisions of the Criminal Procedure Code. In general terms, see Art. 89 (3) of the Criminal Procedure Code: "Evidence obtained through unlawful coercion or a threat of such coercion may not be used in proceedings unless it is used as evidence against a person who has used such coercion or threat of coercion."

55 "Taxpayers are subject to both administrative penalties and criminal sanctions if they want to comply their reporting and payment obligations" (Alink, Kommer, 2011).

${ }^{56}$ On various aspects of this principle in relation to European law and the decision-making activities of the European Court of Human Rights, see the collection of contributions by Bockel (2016).

${ }^{57}$ Decision of the Supreme Court of the Czech Republic of 4. 1. 2017, file no. 15 Tdo 832/2016.

${ }^{58} A$ and $B$ v. Norway, judgment of the European Court of Human Rights, 15. 11. 2016, complaint numbers 24130/11 and 29758/11.
} 
of res iudicata with a decision in criminal proceedings if there is a sufficiently close temporal and factual connection between the tax and the criminal proceeding. Adherence to the condition of coherence is not easy, as tax and criminal proceedings are conducted by different bodies, whose activities are in principle unrelated ${ }^{59}$ I believe, however, that such concept is contrary to the principle of ne bis in idem, since its essence is the prohibition of double punishment, i.e. the idea that the state should punish one act in only one way; ${ }^{60}$ and the connection between the two proceedings is irrelevant in that regard. ${ }^{61}$

If a collateral proceeding is taking place within a criminal proceeding in relation to the criminal offence of tax evasion (Art. 240 of the Criminal Code), the tax proceeding is considered an obstacle as defined in Art. 44 (3) of the Criminal Procedure Code for the tax administrator to exercise its claim in the collateral proceeding. ${ }^{62}$ There are tendencies, however, to leave the possibility for the tax administrator to exercise the claim for damages in the collateral proceeding against the offender - a natural person - who acted as a legal entity (taxpayer) apparently without means. ${ }^{63}$

\section{Conclusion}

To define the relationship between criminal proceedings and the other proceedings - in the case of economic crime, particularly civil litigation, insolvency and tax proceedings is one of the most complex problems, given the obvious overlap of the different branches. However, if the prosecuting authority becomes aware of the purposes of each proceeding, the differences in the principles by which they are governed and the legislation in question (in the light of the relevant case law), its conduct is generally correct. In any case, legal norms are not always unambiguous - for instance, in the issue of the so-called punitive damages, the relationship between collateral proceedings and insolvency proceedings or the nature of penalties under Art. 251 of the Tax Code, a legislative change could therefore be considered from the perspective of de lege ferenda.

\section{References}

Alink, M., Kommer van, V. (2011). Handbook on tax administration. Amsterdam: InterAmerican center of tax administrations.

Aristotle. (2004). Nicomachean Ethics (R. Crisp, Ed.). Cambridge University Press. Ashworth, A., Horder, J. (2013). Principles of criminal law. Oxford: Oxford University Press.

\footnotetext{
${ }^{59}$ E.g. in Austria, United Kingdom and the USA, the tax authorities are authorised also to conduct (criminal) investigation (Seer, Wilms, Radvan, 2016).

${ }^{60}$ The prohibition of double punishment ("Doppelbestrafungsverbot") has historically been recognised as a principle in European legal systems (Mansdörfer, 2004).

${ }^{61}$ The Italian approach can be considered the "most elegant" solution to prevent the principle of ne bis in idem from being violated, where a special provision determines the form of the sanction when the two possible sanctions coincide (Seer, Wilms, Radvan, 2016).

${ }^{62}$ See the Decision of the Supreme Court of the Czechoslovak Socialist Republic of 31. 7. 1985, file no. 3 To $9 / 85$.

${ }^{63}$ Decision of the Supreme Court of the Czech Republic of 8. 1. 2014, file no. 15 Tdo 902/2013.
} 
Bakeš, M. (1999). Finanční právo. Praha: C. H. Beck.

Bakeš, M. (2012). Finanční právo. Praha: C. H. Beck.

Balzer, Ch., Walther, B. (2018). Beweisaufnahme und Beweiswürdigung im Zivilprozess: eine Anleitung für die gerichtliche und anwaltliche Praxis. Berlin: Erich Schmidt Verlag. Berolzheimer, F. (1903). Die Entgeltung im Strafrechte. München: C. H. Beck'sche Verlagsbuchhandlung Oskar Beck.

Binding, K. (1872). Die Normen und ihre Übertretung: Eine Untersuchung über die rechtmässige Handlung und die Arten des Delikts. Leipzig: Verlag von Wilhelm Engelmann.

Bockel, B. (2016). Ne bis in idem in EU law. Cambridge: Cambridge University Press.

Fink, H. (2017). Insolvenzrecht. Wien: LexisNexis.

Gerloch, A., Beran, K. (2014). Funkce a místo právní odpovědnosti v recentním právním řádu. Praha: Leges.

Janeček, V. (2017). Kritika právní odpovědnosti. Praha: Wolters Kluwer.

Jelínek, J. (2017). Jak dál s trestním stíháním se souhlasem poškozeného? Kriminalistika: čtvrtletník pro kriminalistickou teorii a praxi, 2017 (1), 5-6.

Klein, F., Engel, F. (1927). Der Zivilprozess Oesterreichs. Wien: J. Bensheimer.

Knapp, V. (1983). Obecně teoretické poznámky k otázce diferenciace právní odpovědnosti. In Růžek, A. Diferenciace trestní odpovědnosti: sborník dokumentů a př́spěvků z kolokvia Československé národní skupiny AIDP s mezinárodní účastí, konaného ve dnech 23. až 24. záři 1981 v Praze. Praha: Karlova univerzita.

Kotlán, P. (2015). Tunelování obchodních společností. Kriminalistika: časopis pro kriminalistickou teorii a praxi, 2015 (4), 254-264.

Kotlán, P. (2018a). Princip subsidiarity trestní represe a judikatura Nejvyššího soudu ČR. In Dny práva 2017 - Days of Law 2017. Part IX. Brno: Masarykova univerzita, 149-152. Kotlán, P. (2018b). Problematické aspekty práv poškozeného v přípravném řízení trestním. In FRYŠTÁK, M. (ed.). Cofola 2018. Part VI. Brno: Masarykova univerzita, 92-93.

Lavický, P. (2017). Důkazní břemeno v civilním řízení soudním. Praha: Leges.

Mansdörfer, M. (2004). Das Prinzip des ne bis in idem im europäischen Strafrecht. Berlin: Duncker \& Humblot.

Meurkens, L., Nordin, E. (2012). The power of punitive damages - is Europe missing out? Cambridge: Intersentia.

Musil, J., Kratochvíl, V., Šámal, P. (2003). Kurs trestního práva: trestní právo procesní. Praha: C. H. Beck.

Nagel, H. (1967). Die Grundzüge des Beweisrechts im europäischen Zivilprozeß: eine rechtsvergleichende Studie. Baden-Baden: Nomos Verlagsgesellschaft.

Pelz, Ch. (2011). Strafrecht in Krise und Insolvenz. München: Verlag C. H. Beck.

Petrák, M. (2016). Insolvenční řízení, státní zástupce a $\$ 206$ odst. 4 trestního řádu aneb počátek a konec adhezního řízení v (přípravném) řízení trestním. Státní zastupitelství: profesní časopis státních zástupců a státního zastupitelství České republiky, 2016 (4), 35. Provazník, J. (2019). Trestný čin maření spravedlnosti. Státní zastupitelství: profesní časopis státních zástupců a státního zastupitelství České republiky, 2019 (3), 32-45.

Púry, F. (2015). Úpadkové trestné činy v České republice. Praha: C. H. Beck. 
Rechberger, W. H., Seeber, T., Thurner, M. (2018). Insolvenzrecht. Wien: Facultas.

Roxin, C. (1973). Kriminalpolitik und Strafrechtssystem. Berlin: Walter de Gruyter.

Seer, R., Wilms, A. L., Radvan, M. (2016). Surcharges and penalties in tax law: 2015 EATLP congress Milan, 28-30 May 2015. Amsterdam: IBFD.

Storch, F., Spáčil, J. (2011). Řízení trestní rakouské. Praha: Wolters Kluwer Česká republika.

Vašutová, V. (2012). Specifika dokazování v daňovém řizení. Brno: Masaryk University, Faculty of Law. Rigorous thesis.

Winterová, A., Macková, A. (2015). Civilní právo procesní. Part I-II. Praha: Leges. 